Original Article

\title{
A SIMPLE AND RUGGED BIOANALYTICAL METHOD DEVELOPMENT AND VALIDATION OF BRIVUDINE IN HUMAN PLASMA BY USING HIGH-PERFORMANCE LIQUID CHROMATOGRAPHY
}

\section{S. SATHESHKUMAR ${ }^{*}$, V. MURUGANANTHAM ${ }^{2}$}

${ }^{1,2}$ Department of Pharmaceutics, College of Pharmacy, Vinayaka Mission's College of Pharmacy, Salem 636008, Tamilnadu, India Email: sat2794@gmail.com

Received: 01 Apr 2020, Revised and Accepted: 13 May 2020

\section{ABSTRACT}

Objective: The current research work focus to simple and rugged bioanalytical method development and validation of brivudine in human plasma using high-performance liquid chromatography.

Methods: The analyte (Brivudine) and internal standard (Sofosbuvir) were extracted using the Solid Phase Extraction (SPE) technique. The chromatographic separation was accomplished by using Zorbax eclipse XDB-C $\mathrm{C}_{18}$ Column $(150 \times 4.6 \mathrm{~mm}, 5 \mu \mathrm{m})$ with a mobile phase consisted of Methanol: $0.5 \%$ Ortho-phosphoric acid $(65: 35 \%, v / v)$ respectively, at a flow rate of $0.7 \mathrm{~mL} / \mathrm{min}$. The developed method was validated by performing system suitability, carryover effect, linearity, selectivity, sensitivity, precision, accuracy, recovery, ruggedness, and stability studies. The method was validated as per USFDA guidelines.

Results: The selected chromatographic condition was found to efficiently separated brivudine (RT-3.55 min) and ISTD (RT-7.87 min). The assay demonstrated a linear dynamic range of 85.205 to $4500.246 \mathrm{ng} / \mathrm{ml}$ for brivudine in human plasma with $\mathrm{r}^{2}>0.99$. Demonstrated the lowest limit of detection at $85.205 \mathrm{ng} / \mathrm{ml}$. This method established an intra-run and inter-run precision within the range of $2.99-6.31 \% \mathrm{CV}$ and $3.67-5.80 \% \mathrm{CV}$, respectively. Additional intra-run and inter-run accuracy were within the range of 97.55-105.37\% and 99.27-102.15\%, respectively. The mean percentage recovery of brivudine and ISTD studies proved good extraction efficiency and the robustness was also evaluated.

Conclusion: A simple, accurate, precise, linear and rugged RP-HPLC method was developed and validated for the estimation of brivudine in human plasma with $\mathrm{K}_{2}$ EDTA anticoagulant and suitable for conducting BA/BE and TDM.

Keywords: Brivudine, Human Plasma, Liquid Chromatography, Solid Phase Extraction

(C) 2020 The Authors. Published by Innovare Academic Sciences Pvt Ltd. This is an open access article under the CC BY license (http://creativecommons.org/licenses/by/4.0/) DOI: http://dx.doi.org/10.22159/ijpps.2020v12i7.37703. Journal homepage: https://innovareacademics.in/journals/index.php/ijpps

\section{INTRODUCTION}

It is available as a $125 \mathrm{mg}$ tablet and as a $0.1 \%$ ointment Brivudine is a strong antiviral agent against the varicella-zoster virus and it is an analog of thymidine. It blocks viral replication by interfering with viral DNA through inhibition of deoxythymidine dehydrogenase. It is almost completely absorbed in the gastrointestinal tract after oral administration, but due to extensive first-pass metabolism, bioavailability is about $30 \%$ and extensively bound to plasma proteins (95\% binding), but is not displaced by concomitant drugs, including analgesics, cardiac glycosides, cytostatics and virostatics and excreted mainly in the urine (65\%) with Less than $1 \%$ of unchanged brivudine found in urine, a minor fraction has been found in the faeces (21\%). The terminal half-life has been established at $16 \mathrm{~h}[1]$.

nt for ophthalmologic use [2]. It is also used as eye drops for the treatment of HSV-1 epithelial keratitis [3]. Oral brivudin is now approved in several EU countries (Germany, Italy, Austria, Belgium, Luxembourg, Spain, Portugal and Greece) for the treatment of herpes zoster in immune-competent patients with the dose regimen of one tablet (125 mg) per day for $7 \mathrm{~d}$ [4].

This is expected to work by blocking the activity of a protein called 'heat shock protein 27 (Hsp27), which is found in high amounts in pancreatic cancer cells. Hsp27 is known to play a key role in 'chemoresistance'. When brivudine is given together with other anticancer medicines, it is expected to prevent the cancers cells from developing resistance to the medicines, helping to treat the disease [5].

Systematic (IUPAC) name: 5-[(1E)-2-bromoethenyl]-1-[(2R, 4S, 5R)4-hydroxy-5-hydroxymethyl) oxolan-2-yl]-1,2,3,4-tetrahydropyrimidine-2,4-dione (fig. 1). It is freely soluble in Methanol and chemical formula is $\mathrm{C}_{11} \mathrm{H}_{13} \mathrm{BrN}_{2} \mathrm{O}_{5}$ with the molecular weight $333.135 \mathrm{~g} / \mathrm{mol}[6]$.<smiles></smiles>

Fig. 1: Chemical structure of brivudine

Drug literature review reveals that few analytical quantification methods have been reported for the brivudine in bulk, formulations, and biological matrices. Which includes UV spectrophotometric [8], capillary electrophoresis $[9,10]$, high performance liquid chromatography coupled with ultraviolet (UV) detection [11, 12] and ultra-high performance liquid chromatography-tandem mass spectrometric detection (UPLC-MS/MS) [13]. The present work designed to develop a simple, rugged, economic and validated RPHPLC method for the determination of brivudine in human plasma with anti-coagulant $\mathrm{K}_{2}$ EDTA.

\section{MATERIALS AND METHODS}

Chemicals and reagents

Brivudine and sofosbuvir bulk drugs were kindly provided as a gift sample by Sequent Labs Pvt. Ltd., Mangalore, India. Analytical grade of ammonium acetate purchased from Rankem Ltd., India and HPLC grade of methanol and acetonitrile purchased from Merck 
Specialties Private Limited, India. Analytical grade orthophosphoric acid purchased from Rankem Ltd., India, Matrix: Human plasma (K2EDTA-Anticoagulant) acquired from a registered blood bank.

\section{Instrument}

Quantitative HPLC was performed on a Shimadzu HPLC system with PDA detector and LC-MS solution software. An agilent Zorbax Eclipse XDB- $\mathrm{C}_{18}$ column of $250 \mathrm{~mm} \mathrm{X} 4.6 \mathrm{~mm}$ : i. d and $5 \mu \mathrm{m}$ particle size with $300^{\circ} \mathrm{A}$ pore size was used. Micro Weighing Balance (MX5)Mettler Toledo, an Ultrasonic bath sonicator, Deep Freezer $(-20 \pm 5$ $\left.{ }^{\circ} \mathrm{C}\right)$-Thermo Fisher Scientific, Refrigerator $\left(2-8{ }^{\circ} \mathrm{C}\right)$-Thermo Fisher Scientific and Vortex-Spinix, Heidolph top were used in the study.

\section{Chromatographic condition}

Chromatography separation was achieved on a reverse-phase zorbax eclipse XDB-C18 column $(250 \times 4.6 \mathrm{~mm}, 5 \mu \mathrm{m})$ with isocratic elution by methanol: $0.5 \%$ 0-phosphoric acid $(65: 35 \%, \mathrm{v} / \mathrm{v})$ as the mobile phase. Chromatographic peaks were resolved by the mobile phase with a flow rate of $0.7 \mathrm{ml} / \mathrm{min}$. The total analysis run time of $10 \mathrm{~min}$ and the analytical column temperature ambient.

\section{Standard solution preparation}

Accurately weighed and transferred $5 \mathrm{mg}$ of Brivudine into $5 \mathrm{ml}$ volumetric flask. The solution is made up to the mark by using Methanol diluent to get the concentration of $1.0 \mathrm{mg} / \mathrm{ml}$ and stored at $2-8^{\circ} \mathrm{C}$.

\section{Working standard preparation}

The working solutions for the calibration standards containing brivudine were prepared by dilution of the stock solution with the diluent $60 \%$ methanol solution $(\mathrm{v} / \mathrm{v})$. Calibration standards in human plasma were prepared by diluting the corresponding working solutions with screened blank plasma samples at the following concentrations: $85.205,170.411,340.141,583.232$, $972.053,1620.088,2700.147$ and $4500.246 \mathrm{ng} / \mathrm{ml}$ for brivudine. The working solutions for the quality control (QC) samples were prepared at the following concentrations: 85.211, 240.030, $1500.188,3500.204$ and $17501.022 \mathrm{ng} / \mathrm{ml}$ for brivudine. ISTD working standard solution at a concentration of $500 \mathrm{ng} / \mathrm{ml}$ was prepared by diluting the stock solution $(1.0 \mathrm{mg} / \mathrm{ml})$ with the diluent. All stock solutions, working solutions, calibration standards and QCs were immediately stored at $2-8^{\circ} \mathrm{C}$.

\section{Sample preparation}

Exactly $0.200 \mathrm{ml}$ of plasma sample was aliquoted and transferred into a tarsons ria vial polypropylene tube and $0.050 \mathrm{ml}$ of ISTD $(500 \mathrm{ng} / \mathrm{ml})$ working concentration solution was added, except for standard blank, to which $0.050 \mathrm{ml}$ of $60 \%$ methanol solution (v/v) was added and vortexed. To this $0.250 \mathrm{ml}$ of $50 \mathrm{mmol}$ ammonium acetate (w/v) was added and vortexed. Sample clean-up was conducted by using the following Solid Phase Extraction procedure, the waters cartridges (Oasis HLB) were first conditioned with methanol $1 \mathrm{ml}$ to activate the chemical bonds then equilibrated by using water $1 \mathrm{ml}$, in a positive pressure manifold SPE. Plasma samples were loaded onto SPE cartridges. Then, the cartridges were washed with water $1 \mathrm{ml}$ twice and followed by $5 \%$ methanol solution $(\mathrm{v} / \mathrm{v}) 1 \mathrm{ml}$ to wash the interferences and the analyte was successively eluted with $0.250 \mathrm{ml}$ of $100 \%$ methanol with elution tarsons ria vial polypropylene tube contained $0.050 \mathrm{ml}$ of $0.5 \%$ orthophosphoric acid solution (v/v).

\section{Method validation}

Method validation was done as per the criteria of industrial guidance for the bioanalytical method validation of USFDA [14-16].

\section{System suitability}

System suitability experiment was performed by injecting six repeated injections using a standard aqueous mixture equivalent to an approximately middle concentration of the calibration curve of brivudine and working concentration of ISTD during the start of the method validation and at the start of the respective day. The Area ratio of system suitability has within the acceptance limits of $5 \% \mathrm{CV}$.

\section{Carryover effect}

Carryover effect was performed in order to eliminate the carryover from the previous injection to the next injection. Extracted blank, extracted LLOQ, and extracted ULOQ samples were prepared from same biological matrix lot. These samples were injected in the order of mobile phase, extracted blank plasma, extracted LLOQ, extracted ULOQ and extracted blank plasma samples during the start of the method validation. The response of interfering peaks at the retention time of analyte has $\leq 20 \%$ of the response of extracted LLOQ and at the retention time of ISTD have $\leq 5 \%$ of response of extracted LLOQ.

\section{Selectivity/Sensitivity}

The selectivity of the method was assessed by analysing human blank plasma samples as of different healthy human volunteer's six lots from a normal plasma source, two lots from lipemic source and two lots from haemolysed source, to investigate the potential interferences of endogenous compounds at the LC peak region for brivudine and ISTD. The sensitivity of the method was determined with the LLOQ level of the analyte with PandA. The peak area of LLOQ for brivudine and ISTD at corresponding retention time in blank samples should not be more than $20 \%$ and $5 \%$ of the mean peak area of sofosbuvir.

\section{Linearity}

Linearity of the plasma samples was quantified using the peak-area ratio versus analyte nominal concentration. A calibration curve was constructed using linear regression and it consists of a standard blank sample, a standard Zero sample (Blank sample+ISTD) and eight non-zero samples which are distributed throughout the calibration range $85.205-4500.246 \mathrm{ng} / \mathrm{ml}$ of brivudine. The acceptance limit for a calibration curve was a correlation coefficient $\left(\mathrm{r}^{2}\right)$ of 0.98 or Greeter, and each back-calculated standard concentration should be $\pm 15 \%$ deviation from the nominal value except LLOQ, which was set at $\pm 20 \%$.

\section{Precision and accuracy}

Precision and Accuracy batch was assessed by analyzing three batches. For P and A studies five concentration QC samples were prepared as (LLOQ) Lower Limit of Quantification, (LQC) Lower Quality Control, (MQC) Medium Quality Control, (HQC) High-Quality Control and (DIQC) Dilution Integrated Quality Control corresponding to $85.211,240.030,1500.188,3500.204$ and $17501.022 \mathrm{ng} / \mathrm{ml}$ respectively, with six replicates each. The intra-run and inter-run precision (\% CV) for LOQ, MQC, HQC and DIQC should be $\leq 15 \%$ except for LLOQ, which was set at $\leq 20 \%$ and the intra-run and inter-run accuracy for LOQ, MQC, HQC and DIQC should be within $\pm 15 \%$ except for LLOQ, which was set at within $\pm 20 \%$.

\section{Recovery}

The percentage recovery of brivudine from human plasma was determined by comparing the mean peak area of six extracted LQC, MQC and HQC (240.030, 1500.188, and $3500.204 \mathrm{ng} / \mathrm{ml}$ ) respectively, quality control samples to the mean peak area of six post-extracted LQC, MQC and HQC quality control samples with the same concentrations.

The percentage recovery of ISTD from human plasma was determined by comparing the mean peak area of the prepared extracted ISTD to the mean peak area of Post extracted ISTD at the concentration level intended for use.

\section{$\%$ recovery of ISTD has to be less than $110 \%$.}

\section{Dilution integrity}

Dilution integrity was assessed to ensure that samples could be diluted with a screened blank matrix without affecting the final concentration. Brivudine spiked human plasma samples were prepared at concentrations of $17501.022 \mathrm{ng} / \mathrm{ml}$, above the upper limit of the calibration range. These solutions were further diluted with human pooled plasma five times dilution in six replicates and analysed with PandA parameters. The six replicates have a precision of $\leq 15 \% \mathrm{CV}$ and accuracy of $100 \pm 15 \%$. 


\section{Ruggedness}

The ruggedness of the method was studied by changing the experimental condition with a precision and accuracy batch. The batch was monitored using a similar type column of another manufacture (Phenomenex Luna $\mathrm{C}_{18}$ ) and different analyst in the same laboratory.

\section{Stability experiments}

The stability was calculated by analysing quality control samples and comparing the found concentration to the nominal concentration values.

\section{Stock solution stability}

The aqueous stock solutions were prepared and kept at $2-8^{\circ} \mathrm{C}$ for 44 d. The mean peak response of the stored stock solution of analyte and ISTD versus the comparable freshly prepared stock solution and immediately analysed.

\section{Bench-top stability}

Stability of analyte was analysed in the plasma after $8 \mathrm{~h} 30 \mathrm{~min}$ at room temperature was determined with six replicates of quality control samples at LQC and HQC concentration levels.

\section{Freeze-thaw stability}

Six replicates of stability quality control samples (LQC and HQC) were stored in the deep freezer at- $20^{\circ} \mathrm{C}$. Thawed at room temperature, followed by freezing for minimum $12 \mathrm{hr}$. The QC samples were subjected to five freeze-thaw cycles before being extracted and analysed.

\section{Auto-sampler stability}

Six replicates of stability quality control samples (LQC and HQC) were processed and left in the auto-sampler rack for $16 \mathrm{~h} 30 \mathrm{~min}$ at $4{ }^{\circ} \mathrm{C}$ and then injected and quantified.

\section{Wet extract stability}

Six replicates of stability quality control samples (LQC and HQC) were processed and stored in wet extract form at $2-8{ }^{\circ} \mathrm{C}$ in the refrigerator for $24 \mathrm{~h}$.

\section{Long-term plasma stability}

For long term stability, three sets of quality control samples (LQC, HQC and DIQC) were stored in the deep freezer at- $20{ }^{\circ} \mathrm{C}$ for $44 \mathrm{~d}$. The Stability plasma samples were extracted and analysed using freshly prepared calibration standards and run acceptance QC's.

All stability parameters were considered to be stable if assay values were within the acceptable tolerance of accuracy (i. e $\pm 15 \%$ Bias) and precision (i. e $\leq 15 \% \mathrm{CV}$ ).

\section{RESULTS AND DISCUSSION}

\section{System suitability}

The system suitability \%CV of the retention time was found to be $0.41-1.55 \%$ for the analyte and $0.33-2.61 \%$ for ISTD. The $\%$ CV of the peak area ratio was found to be $2.33-4.10 \%$. The results were found to be within tolerance and are presented in table 1.

\section{Carryover effect}

The result observed that no carryover was found during this method for both analyte and ISTD and it does not affect the precision and accuracy. The result was summarized in table 2 .

\section{Selectivity/sensitivity}

The selectivity of the method was demonstrated on ten blank plasma samples obtained from different lots. The chromatograms were found to be free from significant endogenous interferences. These batches were further selected for the preparation of standard CC and
QC samples and the \% bias of LLOQ samples was within the acceptable range of $\pm 20 \%$.

\section{Linearity}

The linearity of the method was demonstrated for brivudine in the concentration range of 85.205-4500.246 ng/ml) fig. 4 at eight nonzero sample points. The correlation coefficients $\left(\mathrm{r}^{2}\right)$ for the standard curves ranged from 0.9989 to 0.9997 for brivudine. The result was summarized in table 3 .

\section{Precision and accuracy}

The intra-run and inter-run accuracy for each concentration level was within the range of $97.55-105.37 \%$ and $99.27-102.15 \%$, respectively, and the intra-run and inter-run precision for each concentration level within the range of 2.99-6.31\%CV and 3.67-5.80 $\% \mathrm{CV}$, respectively. The intra-run and inter-run precision and accuracy of the method are presented in table 4.

\section{Recovery}

The mean \% recovery for LQC, MQC and HQC samples of brivudine were found to be $78.74 \%, 74.08 \%$ and $67.50 \%$ respectively. The mean \% overall recovery of analyte was found to be $73.44 \%$ with acceptable precision of $7.69 \% \mathrm{CV}$ and the ISTD \% mean recovery was found to be $69.73 \%$ at MQC level. The result was summarized in table 5.

\section{Dilution integrity}

Dilution integrity of brivudine was performed and evaluated. The percentage nominal was found within the limit of $\pm 15 \%$ and the estimated precision was $\leq 15 \%$ and an accuracy of $100 \pm 15 \%$. It shows that the drug can be diluted to five times and the results will be reproducible and are presented in table 4 .

\section{Ruggedness}

The current method indicated good ruggedness when it is performed by using different analyst and different columns. The results of the ruggedness were found to be within the acceptance limit and are presented in table 6.

\section{Stability}

The $\%$ bias of stock solutions stability was tested for analyte and ISTD and established under refrigerator condition $2-8{ }^{\circ} \mathrm{C}$ for $44 \mathrm{~d}$ and results were found to be within the range of $\pm 10 \%$. The analyte passed all stability parameter tests viz., Auto-sampler (16 h $30 \mathrm{~min})$, Bench-top ( $8 \mathrm{~h} 30 \mathrm{~min})$, wet extract (24h), Freeze-Thaw (5 cycles) and deep freezer stability at $-20^{\circ} \mathrm{C}$ for at least $44 \mathrm{~d}$. There was no significant decrease in the analyte concentration was observed with a good percentage of accuracy and precision for stability quality control samples. The summary of the stability parameter for brivudine presented in table 7 .

The developed chromatographic method for the quantification of brivudine in human plasma was simple, reproducible and economical, as exposed by the statistical data of analysis. The internal standard used is readily available. The mobile phase is simple to prepare and cost-effective. The analytical assay of brivudine was completed within $10.0 \mathrm{~min}$, revealing the rapidity of the proposed RP-HPLC method. The linearity results showed that an excellent correlation existed between peak area and concentration of brivudine within the concentration range tested. The values of slope and intercept of the calibration graph indicated the good reproducibility of the proposed method. Higher values of correlation coefficient validated the linearity of the calibration plot. PandA results over three analytical batches are meeting the acceptance criteria. Overall percentage mean recovery is $73.44 \%$. The overall mean recovery $\% \mathrm{CV}$ for three QC levels less than $15.00 \%$. Recovery statistical data was found to be within limits. Brivudine was found to be stable as long term shock at $-20^{\circ} \mathrm{C}$ for $44 \mathrm{~d}$. When compared to previous bio-analytical methods [9-13], the developed method was simple, economical and accurate bio-HPLC method in human plasma. 
Table 1: System suitability

\begin{tabular}{|c|c|c|c|}
\hline \multirow[t]{2}{*}{ S. No. } & Brivudine (Analyte) & Sofosbuvir (ISTD) & \multirow[t]{2}{*}{ Area ratio } \\
\hline & Retention time (min) & Retention time (min) & \\
\hline 1 & 3.57 & 7.88 & 0.3144 \\
\hline 2 & 3.52 & 7.80 & 0.3230 \\
\hline 3 & 3.55 & 7.91 & 0.2944 \\
\hline 4 & 3.56 & 7.85 & 0.2975 \\
\hline 5 & 3.58 & 7.92 & 0.3142 \\
\hline 6 & 3.51 & 7.85 & 0.3003 \\
\hline mean $\pm S D$ & 3.55 & 7.87 & 0.3073 \\
\hline$\pm \mathrm{SD}$ & 0.0279 & 0.0445 & 0.0115 \\
\hline$\% \mathrm{CV}$ & 0.79 & 0.57 & 3.74 \\
\hline
\end{tabular}

*Number of injections-6

Table 2: Carry over effect

\begin{tabular}{|c|c|c|c|c|}
\hline Sample name & Analyte area & \% Carryover (analyte) & ISTD area & \% Carryover (ISTD) \\
\hline Briv-Mobile Phase & 0 & 0.00 & 0 & 0.00 \\
\hline Briv-Extracted Blank & 0 & 0.00 & 0 & 0.00 \\
\hline Briv-Extracted LLOQ & 3251 & $\mathrm{~N} / \mathrm{AP}$ & 184527 & $\mathrm{~N} / \mathrm{AP}$ \\
\hline Briv-Extracted ULOQ & 159468 & N/AP & 176238 & N/AP \\
\hline Briv-Extracted Blank & 0 & 0.00 & 0 & 0.00 \\
\hline
\end{tabular}

Table 3: Linearity

\begin{tabular}{|c|c|c|c|c|c|c|c|c|}
\hline STD ID & STD 1 & STD 2 & STD 3 & STD 4 & STD 5 & STD 6 & STD 7 & STD 8 \\
\hline Nominal concentration (ng/ml) & 85.205 & 170.411 & 340.141 & 583.232 & 972.053 & 1620.088 & 2700.147 & 4500.246 \\
\hline $\mathrm{n}$ & 3 & 3 & 3 & 3 & 3 & 3 & 3 & 3 \\
\hline mean \pm SD & 85.798 & 164.098 & 355.289 & 612.077 & 973.657 & 1688.178 & 2851.115 & 4627.626 \\
\hline$\pm \mathrm{SD}$ & 3.33 & 3.61 & 7.15 & 16.91 & 55.09 & 86.55 & 102.07 & 138.22 \\
\hline$\% \mathrm{CV}$ & 3.88 & 2.20 & 2.01 & 2.76 & 5.66 & 5.13 & 3.58 & 2.99 \\
\hline$\%$ Accuracy & 100.70 & 96.30 & 104.45 & 104.95 & 100.17 & 104.20 & 105.59 & 102.83 \\
\hline
\end{tabular}

*Number of each concentration injections-3

Table 4: back-calculated concentrations for quality control samples (Intra-run and inter-run precision and accuracy)

\begin{tabular}{|c|c|c|c|c|c|}
\hline PA No. & $\begin{array}{l}\text { LLOQ } \\
85.211 \mathrm{ng} / \mathrm{ml} \\
\end{array}$ & $\begin{array}{l}\text { LQC } \\
240.030 \mathrm{ng} / \mathrm{ml}\end{array}$ & $\begin{array}{l}\text { MQC } \\
1500.188 \mathrm{ng} / \mathrm{ml}\end{array}$ & $\begin{array}{l}\mathrm{HQC} \\
3500.204 \mathrm{ng} / \mathrm{ml}\end{array}$ & $\begin{array}{l}\text { DIQC } \\
17501.022 \mathrm{ng} / \mathrm{ml}\end{array}$ \\
\hline $\mathrm{n}$ & 6 & 6 & 6 & 6 & 6 \\
\hline Intra-run mean $\pm S D$ & 87.170 & 235.249 & 1580.80 & 3560.44 & 18271.84 \\
\hline Intra-run $\pm S D$ & 4.30 & 7.02 & 96.71 & 176.53 & 1152.36 \\
\hline Intra-run \%CV & 4.94 & 2.99 & 6.12 & 4.96 & 6.31 \\
\hline Intra-run $\%$ Accuracy & 102.30 & 98.01 & 105.37 & 101.72 & 104.40 \\
\hline $\mathrm{n}$ & 6 & 6 & 6 & 6 & 6 \\
\hline Intra-run mean $\pm S D$ & 85.704 & 234.159 & 1525.753 & 3475.642 & 17965.238 \\
\hline Intra-run $\pm S D$ & 4.82 & 7.40 & 58.86 & 210.38 & 937.67 \\
\hline Intra-run $\% \mathrm{CV}$ & 5.62 & 3.16 & 3.86 & 6.05 & 5.22 \\
\hline Intra-run \% Accuracy & 100.58 & 97.55 & 101.70 & 99.30 & 102.65 \\
\hline $\mathrm{n}$ & 6 & 6 & 6 & 6 & 6 \\
\hline Intra-run mean \pm SD & 88.268 & 245.448 & 1488.788 & 3430.830 & 17299.037 \\
\hline Intra-run $\pm S D$ & 4.38 & 9.38 & 93.65 & 134.80 & 834.32 \\
\hline Intra-run \%CV & 4.97 & 3.82 & 6.29 & 3.93 & 4.82 \\
\hline Intra-run \% Accuracy & 103.59 & 102.26 & 99.24 & 98.02 & 98.85 \\
\hline $\mathrm{n}$ & 18 & 18 & 18 & 18 & 18 \\
\hline Inter-run mean $\pm S D$ & 87.047 & 238.286 & 1531.780 & 3488.971 & 17845.371 \\
\hline Inter-run $\pm S D$ & 4.52 & 8.75 & 83.07 & 180.36 & 1035.49 \\
\hline Inter-run $\% \mathrm{CV}$ & 5.20 & 3.67 & 5.42 & 5.17 & 5.80 \\
\hline Inter-run \% Accuracy & 102.15 & 99.27 & 102.11 & 99.68 & 101.97 \\
\hline
\end{tabular}

*Number of each concentration injections-6

Table 5: Recovery

\begin{tabular}{|c|c|c|c|c|c|c|c|c|}
\hline \multirow[t]{2}{*}{ QC ID } & \multicolumn{2}{|l|}{ LQC } & \multicolumn{2}{|l|}{ MQC } & \multicolumn{2}{|l|}{ HQC } & \multicolumn{2}{|l|}{ ISTD } \\
\hline & $\begin{array}{l}\text { Post } \\
\text { extracted } \\
\text { area }\end{array}$ & $\begin{array}{l}\text { Extracted } \\
\text { area }\end{array}$ & $\begin{array}{l}\text { Post } \\
\text { extracted } \\
\text { area }\end{array}$ & $\begin{array}{l}\text { Extracted } \\
\text { area }\end{array}$ & $\begin{array}{l}\text { Post } \\
\text { extracted } \\
\text { area }\end{array}$ & $\begin{array}{l}\text { Extracted } \\
\text { area }\end{array}$ & $\begin{array}{l}\text { Post } \\
\text { extracted } \\
\text { area }\end{array}$ & $\begin{array}{l}\text { Extracted } \\
\text { area }\end{array}$ \\
\hline $\mathrm{n}$ & 6 & 6 & 6 & 6 & 6 & 6 & 6 & 6 \\
\hline mean $\pm S D$ & 10990 & 8653 & 78700 & 58300 & 206637 & 139485 & 244963 & 170808 \\
\hline$\pm \mathrm{SD}$ & 395 & 351 & 2603 & 3391 & 7286 & 9517 & 10887 & 5324 \\
\hline$\% \mathrm{CV}$ & 3.59 & 4.06 & 3.31 & 5.81 & 3.53 & 6.82 & 4.44 & 3.12 \\
\hline$\%$ Recovery & 78.74 & & 74.08 & & 67.50 & & 69.73 & \\
\hline$\%$ Global CV & 7.69 & & & & & & - & \\
\hline$\%$ Global recovery & 73.44 & & & & & & - & \\
\hline
\end{tabular}

*Number of injections-6 
Table 6: Ruggedness

\begin{tabular}{|c|c|c|c|c|c|}
\hline PandA & $\begin{array}{l}\text { LLOQ } \\
85.211 \mathrm{ng} / \mathrm{ml}\end{array}$ & $\begin{array}{l}\text { LQC } \\
240.030 \mathrm{ng} / \mathrm{ml}\end{array}$ & $\begin{array}{l}\text { MQC } \\
1500.188 \mathrm{ng} / \mathrm{ml}\end{array}$ & $\begin{array}{l}\text { HQC } \\
3500.204 \mathrm{ng} / \mathrm{ml}\end{array}$ & $\begin{array}{l}\text { DIQC } \\
17501.022 \mathrm{ng} / \mathrm{ml}\end{array}$ \\
\hline $\mathrm{n}$ & 6 & 6 & 6 & 6 & 6 \\
\hline Intra-run mean \pm SD & 79.260 & 227.333 & 1529.991 & 3583.002 & 17548.005 \\
\hline Intra-run $\pm \mathrm{SD}$ & 1.58 & 9.63 & 71.93 & 198.80 & 822.62 \\
\hline Intra-run \%CV & 2.00 & 4.24 & 4.70 & 5.55 & 4.69 \\
\hline Intra-run \% Accuracy & 93.02 & 94.71 & 101.99 & 102.37 & 100.27 \\
\hline
\end{tabular}

*Number of each concentration injections-6

Table 7: Stability

\begin{tabular}{|c|c|c|c|c|c|}
\hline Stability experiment & QC ID & $\begin{array}{l}\text { Nominal } \\
\text { concentration }(\mathrm{ng} / \mathrm{ml})\end{array}$ & $\begin{array}{l}\text { Concentration found } \\
(\mathrm{ng} / \mathrm{ml})(\text { mean } \pm S D)^{*}\end{array}$ & $\begin{array}{l}\text { Precision } \\
\text { (\% RSD) }\end{array}$ & Accuracy (\%) \\
\hline Benchtop & LQC & 240.030 & 247.259 & 5.28 & 103.01 \\
\hline Stability & HQC & 3500.204 & 3410.719 & 7.72 & 97.44 \\
\hline Freeze-thaw & LQC & 240.030 & 244.894 & 7.38 & 102.03 \\
\hline Stability & HQC & 3500.204 & 3515.815 & 4.45 & 100.45 \\
\hline Wet extract & LQC & 240.030 & 238.023 & 3.36 & 99.16 \\
\hline Stability & HQC & 3500.204 & 3574.314 & 5.24 & 102.12 \\
\hline Autosampler & LQC & 240.030 & 248.148 & 4.65 & 103.38 \\
\hline Stability & HQC & 3500.204 & 3498.503 & 4.12 & 99.95 \\
\hline Long term plasma & LQC & 240.030 & 234.321 & 4.26 & 97.62 \\
\hline \multirow[t]{2}{*}{ stability } & HQC & 3500.204 & 3565.980 & 4.72 & 101.88 \\
\hline & DIQC & 17501.022 & 17115.229 & 3.86 & 97.80 \\
\hline
\end{tabular}

*Number of each concentration injections-6

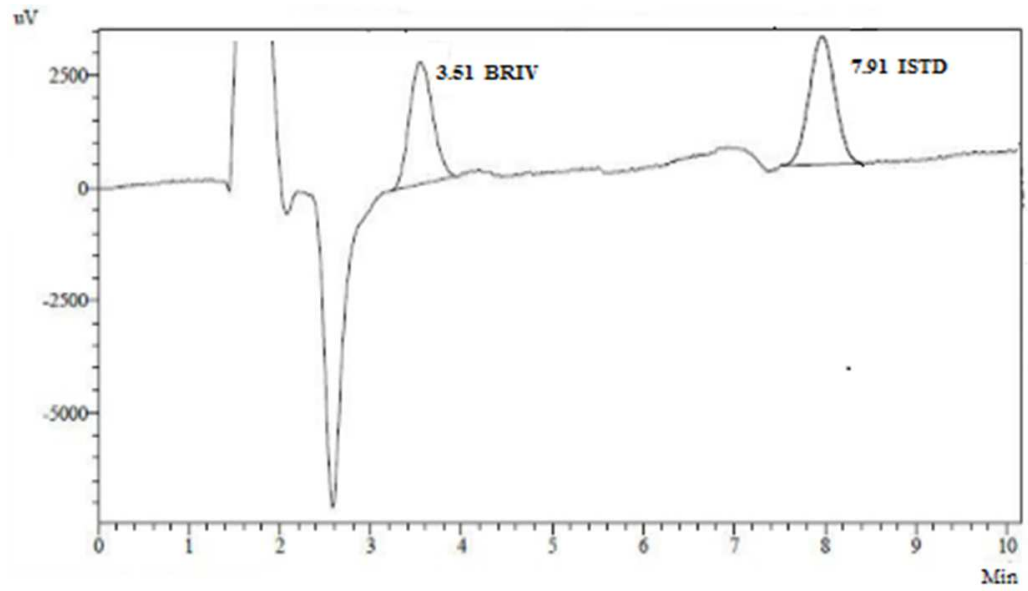

Fig. 2: Extracted LLOQ of brivudine

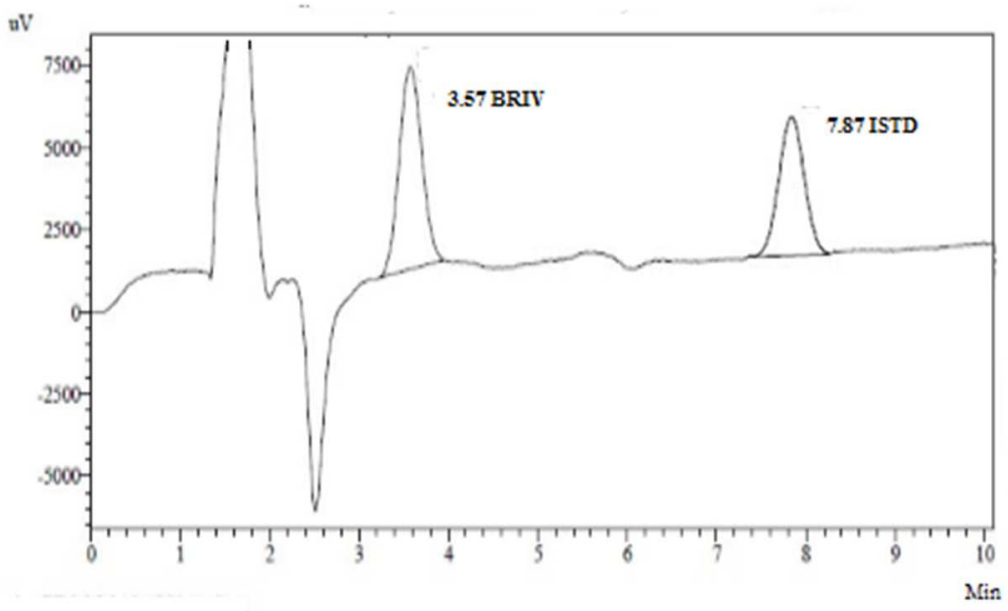

Fig. 3: Extracted ULOQ of brivudine 


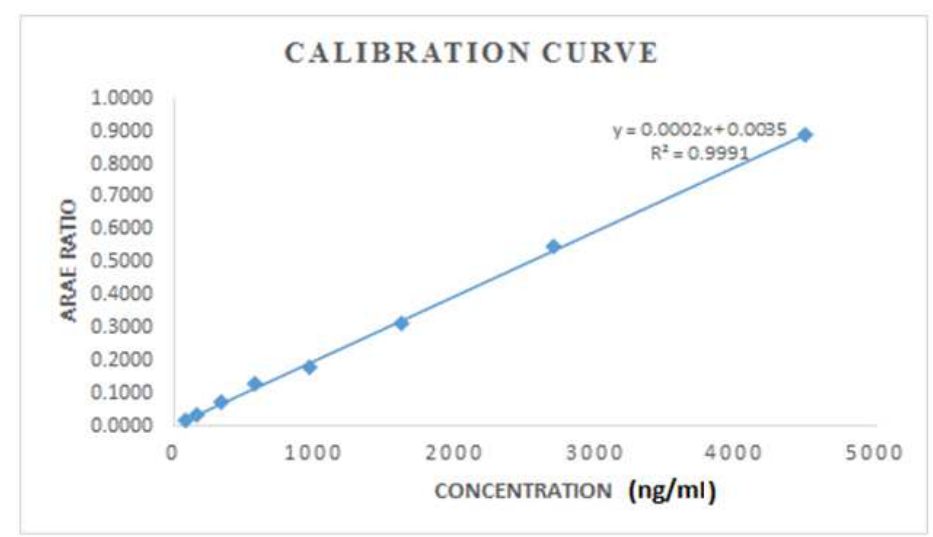

Fig. 4: Calibration curve of brivudine

\section{CONCLUSION}

A simple, accurate, precise, linear and rugged bioanalytical HPLC method for the brivudine was developed and validated with sofosbuvir used as ISTD. The developed method was validated according to the USFDA regulatory guidelines procedure (May2018) and all the validation parameters were within the acceptable range. Hence, the method can use for application in bioavailability/bioequivalence (BA/BE) studies and Therapeutic Drug Monitoring (TDM) with desired precision and accuracy along with high throughput.

\section{FUNDING}

\section{Nil}

\section{AUTHORS CONTRIBUTIONS}

Both author have contributed equally.

\section{CONFLICT OF INTERESTS}

Declared none

\section{REFERENCES}

1. Rabasseda X. Brivudine a herpes virostatic with rapid antiviral activity and once-daily dosing. Drug Today 2003;39:359-71.

2. Salvaggio MR, Gnann. JW JR. Drugs for herpesvirus infections. Anti-Infective Therapy 2004;153:1309-17.

3. De Clercq E, Lia G. Approved antiviral drugs over the past $50 \mathrm{Y}$. Clin Microbiol Rev 2016;29:696-47.

4. Wassilew SW. Brivudin compared with famciclovir in the treatment of herpes zoster effects in acute disease and chronic pain in immune-competent patients. A randomized, doubleblind, multinational study. Eur Acad Dermatol Venereol JEADV 2005;19:47-55.

5. European Medicines Agency Report for brivudine. Committee for Orphan Medicinal Products EMA/COMP/768295/2009; 2010.
6. https://www.drugbank.ca/drugs/DB03312 [Last accessed on 10 Jun 2019]

7. Public Assessment Report for brivudine. ZosterGalen $125 \mathrm{mg}$ Tabletten, DE/H/5591/001/DC; 2019.

8. Binu V, Sangeetha S. Method development and validation of brivudine by UV spectrophotometric method. Int J Curr Adv Res 2018;5:12276-80.

9. Olgemoller J, Hempel G, Boos J, Blaschke G. Determination of (E)-5-(2-bromovinyl)-29-deoxyuridine in plasma and urine by capillary electrophoresis. J Chromatogr B 1999;726:261-8.

10. Reeuwijk HJEM, Tjaden UR, Greef JVD. Development and validation of a bioanalytical assay for (E)-5-(2-promo vinyl)29-deoxyuridine in plasma by capillary zone electrophoresis. J Chromatogr B 1999;726:269-76.

11. Ayisi NK. High-performance liquid chromatographic analysis of (E)-5-(2-bromovinyl)-Z'deoxyuridine and its metabolites in serum, urine and herpes simplex virus type-l infected cells. J Chromatogr 1986;375:423-30.

12. Reeuwijk HJEM, Lingeman H, Tjaden UR, Bruijn EAD, Keizer HJ Greef JVD. Bioanalysis of (e)-5-(2-bromovinyl)-2'deoxyuridine. J Chromatogr 1988;428:93-102.

13. Peng XD, Tan ZR, Wu HZ, Zhou G, Guo CX, Pei Q, et al. LC-MSMS quantitative determination of brivudine in human plasma and its application to pharmacokinetic studies. Chromatographia 2011;73:1089-95.

14. Food and drug Administration. Guidance for Industry: bioanalytical method validation. Rockville MD: US Department of Health and Human Services, Food and Drug Administration. Centre for Drug Evaluation and Research; 2018.

15. Tijare LK, Rangari NT, Mahajan UN. A review on bioanalytical method development and validation. Asian J Pharm Clin Res 2016;9:6-10.

16. Dyade GK, Sawant RL. Simple bioanalytical quantification method for simultaneous estimation of simvastatin and ezetimibe in human plasma by reverse-phase highperformance liquid chromatography technique. Asian J Pharm Clin Res 2020;13:160-5. 